Jurnal ASPIKOM, Vol. 5, No. 2, July 2020, pp. 322-337

P-ISSN: 2087-0442, E-ISSN: 2548-8309

DOI: http://dx.doi.org/10.24329/aspikom.v5i2.692

\title{
Environmental Communication Model in Bengkalis's Mangrove Ecotourism Development
}

\section{Model Komunikasi Lingkungan dalam Pengembangan Ekowisata Mangrove di Kabupaten Bengkalis}

\author{
Yasir $^{1}$, Nurjanah $^{2}$, Nova Yohana ${ }^{3}$ \\ 1,2,3Universitas Riau, Jl. HR Soebrantas, Km 12,5 Pekanbaru 28293, Indonesia \\ *Corresponding author, e-mail: yasir@lecturer.unri.ac.id
}

\begin{abstract}
Damage to mangrove forests and abrasion are the main problems on the coast of the Bengkalis Regency. Conservation of mangrove forests by making community-based ecotourism is the best solution to this problem. This paper aims to explain the environmental communication model in the development of mangrove ecotourism. This research used a qualitative method with case studies. The results showed that environmental communication is an essential component in the successful development of mangrove ecotourism. Environmental communication planning had at least four stages, namely problem analysis, audience analysis, and goal setting; selection of communication channel and media; message development and media production; and implementation accompanied by evaluation. The model of environmental communication in the development of mangrove ecotourism in Bengkalis Regency was carried out by empowering community groups based on deliberation and mutual cooperation. Environmental communication must be integrated and managed creatively by using various communication methods and channels.
\end{abstract}

Keywords: Communication planning; environmental communication; ecotourism; empowerment; mangroves

\section{Abstrak}

Kerusakan hutan bakau dan abrasi merupakan masalah utama di pesisir Kabupaten Bengkalis. Pelestarian hutan bakau dengan menjadikan ekowisata yang berbasis komunitas menjadi solusi terbaik mengatasi masalah ini. Tulisan ini bertujuan untuk menjelaskan model komunikasi lingkungan dalam pengembangan ekowisata mangrove di Kabupaten Bengkalis. Penelitian menggunakan metode kualitatif dengan studi kasus. Peneliti mengumpulkan data melalui wawancara, observasi dan dokumentasi. Hasil penelitian menunjukkan bahwa komunikasi lingkungan merupakan komponen penting dalam sebuah keberhasilan pengembangan ekowisata mangrove. Perencanaan komunikasi lingkungan setidaknya memiliki tahapan yaitu analisis masalah, khalayak dan penentuan tujuan; pemilihan saluran dan media komunikasi; pengembangan pesan dan produksi media; dan implementasi yang diiringi evluasi. Model komunikasi lingkungan pengembangan ekowisata hutan bakau di Kabupaten Bengkalis dilakukan dengan memberdayakan masyarakat yang berbasis musyawarah dan gotong-royong. Komunikasi lingkungan harus dikelola secara terintergrasi dan kreatif dengan menggunakan berbagai metode dan saluran komunikasi.

Kata Kunci: Ekowisata; komunikasi lingkungan; mangrove; perencanaan komunikasi; pemberdayaan 


\section{Introduction}

In Bengkalis Regency, Mangrove deforestation rate (or only Bengkalis) increases annually. In 2018, the Agency of Environment of Riau Province found 8.090 ha of mangrove loss in Bengkalis. Mostly, the loss is caused by abrasion and high-intensity mangrove exploitation for construction material, wood charcoal, and firewood. In 2014 alone, Bengkalis Island witnessed abrasion that can reach 59 ha per year (Susanto, 2019). Mangrove deforestation also takes place because of illegal demand that comes from Malaysia and land clearing for shrimp farming. Weak law enforcement towards the criminal behind mangrove deforestation exacerbates the situation. Damaged mangrove induces an imbalance in other ecosystems, such as beach erosion, seawater intrusion, shrimp, and fish scarcity, which can reduce the fisherman's income. A high level of abrasion and waves also impact the environment quality of the coastal ecosystem negatively, causing more mangrove regions damaged. With that in mind, developing mangrove ecotourism can be seen as a way forward. Through this ecotourism, the coastal ecosystem is expected to be more sustainable (Putra, Anggoro, \& Kismartini, 2015).

For resolving the problem, the government of Bengkalis via the Agency of Environment empowers a group of people by facilitating and supervising them to develop the mangrove ecotourism. The policy planning of ecotourism development has been regulated in the Regulation of Ministry of Home Affairs, Number 33 of 2009, concerning the Guidance for Ecotourism Development in Local Regions (Pemerintah, 2009). Furthermore, the government has regulated the mangrove management system in the President Regulation of Republic Indonesia, Number 73 of 2012, concerning the National Strategy of Managing Mangrove Ecosystem (Pemerintah Indonesia, 2012). Ecotourism is nature-based tourism, which involves educational aspects and the interpretation of the natural environment and social culture, which focuses on sustaining ecological management (Karta \& Suarthana, 2014).

Community-based ecotourism is an attempt in ecotourism to concentrate on the active roles of the community (Setyowati, 2010). The lives of coastal people community are unique. They should encounter a dangerous ecosystem condition and rely on coastal and ocean resources (Amanah, 2010). Nevertheless, some groups on Bengkalis Island have conserved the mangrove forest and reconditioned some of them into a destination. Villages that have mangrove conservation for ecotourism, among others, are Sebauk Village, Teluk Pambang, Deluk, Penebal. For example, Sebauk Village has an Environment-Care Community (Kelompok Masyarakat Peduli Alam Sekitar/ Kempas), and Penebal Village has a Kedabu Group. In 2016, Kempas won an award from the Agency of Environment of Riau in the category environment savior. Kempas then become a reference or solution model towards mangrove problems in Bengkalis' coasts.

Mangrove ecotourism that is developed by Kempas is a region profoundly affected by sea tides. Therefore, the existence of mangrove forests can sustain the coastal ecosystem and function as habitat for cultivation, ranging from shells, seashells, snails, crabs, to shrimp. The ecosystem of mangrove is complex and composed of coastal flora and fauna that is ecologically and socio-economically beneficial (Rusdianti \& Sunito, 2012). The ecological function of mangroves is to sustain, maintain, and stabilize coastline from abrasion, waves, and tides. Mangrove ecosystem also sustains the habitat of various fishes, birds, and primates, for regenerating, breeding, and finding foods. The social-economical function is to be, to name a few, a source of jobs, construction materials, ecotourism, ponds area (Rusdianti \& Sunito, 
2012).

The success of Kempas in conserving mangrove forest inspires other community groups in Bengkalis that have similar problems. Therefore, the concern of Kempas on the environment and precisely its attempt to transform mangrove conservation areas to ecotourism is essential to be analyzed with environmental communication. Environmental communications need to be established to achieve an agreement among communities, or between communities and government, whether local or central. In this approach, communication is meant to provide a solution to environmental problems that can be attempted collectively through people's behavior and actions independently (Lestari, Paripurno, Kusumayudha, \& Ramadhaniyanto, 2016).

Environmental communication is a constitutive and pragmatic tool for providing an understanding of the environment and its relation with humans (Cox, 2010). Pragmatically, environmental communication activities are entangled with education, alertness, convincement, mobilization, and problem-solving advice to solve environmental problems. Constitutively, environment communication includes the aspect of regulating, arranging, and representing nature and the problems inside it as the subject for human understanding.

Environmental communication is usually defined as the intentional exchange of information, whether in the form of knowledge or environmental policies (Flor \& Cangara, 2018). Another perspective argues that environmental communication is an exchange of message in, for, and about the surrounding human world, and systematic interaction between human and nature. (Jurin, Roush, \& Danter, 2010). Also, environmental communication is often perceived as the use of approach, principles, strategies, and communication techniques for managing and protecting the environments (Flor \& Cangara, 2018). In the context, Flor and Cangara added that environmental communication has three primary functions, namely exchanges or transactions of matter, energy, and information between the environment and other living-system. Environmental communication figures in sustaining any system of life, ranging from organism, ecosystem, to social system.

Environmental communication has a principle that the aim of human communication is mutual understanding. Therefore, communication in the environmental perspective is not only an instrument or supporting tools of environment management implementation but also an integrated part for managing the environment itself (Flor \& Cangara, 2018). Against the background, environmental communication used in this research tries to avoid the assumption of many traditional communication theories that communication is what differentiates humans from environments, humans from nature. This research tries to dessert the binary assumption. In other words, the researcher tries to incorporate nature for analyzing the interaction of a diverse ecosystem in which humans are part of nature. Environmental communication discusses communication to not only reflect but also construct, reproduce, and naturalize the human relations with the environments (Littlejohn \& Foss, 2016). In the same line, this present research used ethnoecology communication. Yenrizal, in his studies, shows that ethnoecology communication is a process of interpreting messages among members of society in interpreting various natural phenomena. The interpretation is based on the relational unity between human and natural environments (Yenrizal, 2016).

In another research, Bakti et al. showed that a communication model that is based on local wisdom in the level of society could establish mutual understanding, agreement, partnership, and collaboration, such as deliberation in friendship or 
neighborhood forum with the customary elders and cultural and tourism practitioner. For example, an interpersonal communication channel between cultural and tourism practitioner with the customary elders and group channels have high conformity and cohesiveness for developing geopark destination that is based on culture and local wisdom in Pangandaran. Indeed, social media that is used to send and receive information strengthen the relationship and social ties among them and develop the tourism destination (Bakti, Sumartias, Damayanti, \& Nugraha, 2018).

Therefore, based on the existing research, without adequate and thoughtful communication, environment management regarding abrasion and mangrove in Bengkalis that is reconstructed into mangrove ecotourism will face many issues. Environmental communication, besides capable of raising people's participation, should also empower the members of the community not to stay still and passive. The members of the community should also be an active source of information. By considering the previous research of similar phenomena, the research attempts to deepen the planning of environmental research of mangrove ecotourism development and its environmental communication model in developing mangrove ecotourism in Bengkalis Regency.

\section{Method}

The research used a qualitative method coupled with a case-study. However, this research also used communication ethnoecology. In this research, communication ethnoecology considered communication notions as essential stepping points in viewing the unity of humans and the environments (Yenrizal, Bajari, Rahmat, \& Iskandar, 2015). Consequently, the researcher approached and understood the problem immediately and participative by interacting with the community and try to feel what they experienced.

The research was conducted in Bengkalis Regency. Bengkalis Regency has a relatively large mangrove forest because the land abounds with peat. It is not surprising if the beach witnesses a rapid abrasion, and recently, it is worsened. Mangrove deforestation due to irresponsible human exploitation also contributes to the aggravation of the beach. The research subjects were mangrove caretaker communities, such as the environment-care community (Kempas) in Sebauk Village and Blukap Group in Teluk Tambang Village; the officers in the Agency of Environment and the Agency of Marine and Fisheries of Bengkalis, village heads, and public figures. The number of informants is eight people, selected purposively.

The researcher collected data by conducting in-depth interviews and discussions with some public figures, as well as observation and documentation. In practice, the researchers tried to bring the notions of ethnoecology communication, namely how communities understand mangrove deforestation and how they solve them. The interviews were conducted to the informants, whether the main informant or the supporting one, that account for eight people. The observation was done by observing directly the object investigated relating to environmental communication in developing mangrove ecotourism. Meanwhile, the researchers also collect documentation by gathering some achievements related to communication activities, regulations, decisions, and policies of the government. The researchers used an interactive model analysis developed by Miles and Huberman (Moleong, 2010). Furthermore, the data were verified by data triangulation. The researcher cross-checked the result with various sources, colleagues, because the researchers were composed of three people and the research time was prolonged, and prolonging the research time. 


\section{Results and Discussion}

The policy design of mangrove ecosystem management has been regulated in the Presidential Regulation Number 73 of 2012 concerning National Strategy on Mangrove Ecosystem Management (Indonesia Government, 2012). Besides, the policy of ecotourism development has been regulated in the Ministry of Home Affairs Regulation Number 33 of 2009 (Government, 2009). The rehabilitation and conservation attempt of mangrove forest for ecotourism development require active participation from local inhabitants as the actor of conversion (Rusdianti and Sunito, 2012). Regarding this issue, the government of the Bengkalis Regency had recruited communities, particularly fisherman groups and coastal inhabitants, to be empowered in rehabilitating and developing mangrove forests as ecotourism. The government encouraged the communities to be deliberate and cooperate to establish local society groups as a step to rehabilitate and develop the mangrove ecosystem. Principally, ecosystem development is strongly related to forest area development comprehensively (Astuti and Widodo, 2018). The ecosystem development that involved local society in managing it could contribute to economic benefits to the society or local government (Ridlwan, Muchsin, and Hayat, 2017).

These government-assisted groups conducted routine meetings that did not only aim to have deliberation (musywarah) but also to keep friendship (silaturahmi). Moreover, the meetings also function as a space to share opinions on overcoming the damage of the mangrove forest environment. Saving Bengkalis Island from abrasion and developing mangrove ecotourism was not only practiced by the communities but also by the government of the Bengkalis Regency and the national government. In this case, the Regulation of Ministry of Home Affairs Number 33 of 2009 concerning Ecotourism Guidance in the Region explains that ecotourism development must contain planning, utilization, and control (Government, 2009). In that regulation, to make a policy, the regional government was obliged to empower its communities and coordinate with some related institutions. The government has made policy and communicated it the society through some empowerment programs by coaching the fisherman groups or social groups. Furthermore, the government programs to overcome abrasion was realized with some methods ranging from building a breakwater to shield mangrove seeds to establishing beach wall in some areas.

The researchers found that some approaches, programs, and methods have been implemented to prevent the mangrove deforestation and increasingly severe abrasion. However, environmental communication had not become the pivotal component to solve the problems. Even if there was a communication plan, the implementation had not been thoroughly integrated. The environmental communication, somehow, could not be separated from a communication plan and strategy to support the policy-making, public participation, and its implementation on environmental concerns (Cangara, 2013; Flor and Cangara, 2018). According to the researcher's observation, the environmental communication plan that was exercised had used some phases, although there were several shortcomings.

\section{Problem Analysis and Determination of Communication Purpose}

This phase consists of a situation analysis and problem identification, participative actor analysis, and determination of communication purposes. The meaning of communication purpose determination is an effort to utilize and focus on the strength of the communication system resulted in making communication more 
effective and efficient (Jurin rt al., 2010). The community was aware and understood the environmental problem, and they are collectively responsible for overcoming the abrasion problem and the damage of mangrove forests, which, unusually, exist on the along the coast of the Bengkalis Island. Aside from the problem of the land damage caused by abrasion, the other crucial problem is the continual logging of mangrove forests for charcoal, firewood, and building material without reforestation (Miswadi, Firdaus, \& Jhonnerie, 2017). These phenomena showed that some people were still lack of environmental awareness. However, some other people already possessed environmental awareness, as stated by the chief of Kempas:

"Initially, Kempas was established because most of our members are fishermen who understand the condition of the coast. Therefore, there is an interest from our members to manage that territory. We tried to find a partner from a government institution. As a result, we cooperated with the Agency of Marine and Fisheries. Then, we discussed with our members by involving one of the officers of the Agency of Marine and Fisheries. Finally, the result of the discussion is a program of mangrove forest." (Interview with Zakaria, Chief of Kempas, February 26, 2019).

People's anxiety and restlessness toward the damage of mangrove forest and abrasion were a form of society's awareness to analyze and overcome the problems. So, developing ecotourism was one of the development alternatives which can solve the problems (Astuti \& Widodo, 2018). Deliberation and cooperation activity became social strength as a common form of communication in solving the problems. Analysis through this deliberation is an attempt to respond to the environmental problems that existed in the mangrove forest. As a joint venture group located in Sebauk Village, Bengkalis District, Kempas was firstly just a group of fish catching. Their keen interest encouraged them to establish and develop mangrove forest tourism and campaign it in order to inspire other groups.

The campaign of environmental communication was exercised as a response to the environmental issue and a need to be better (Jurin et al., 2010). The management of mangrove forests in several villages in Bengkalis Island was not only initiated by some communities but also a part of the government's problem. The Agency of Marine and Fisheries, which then the role was taken over by the Office of Living Environment, also contributed actively to Kempas by delivering the idea of developing mangrove forests as a tourism destination.

\section{Media Selection and Communication Channel}

This phase includes the strategy development of media selection and communication channels and the use of the approach in motivating and mobilizing society. By considering the budget comprehensively, the communication planner should decide which mass media is efficacious in delivering messages and achieving planned aims (Jurin et al., 2010). With mangrove forest development as ecotourism, the Agency of Living Environment of Bengkalis Regency used communication channels like interpersonal, group, and public communication (socialization) and other mass media to raise people's environmental awareness. The channel which relied on the environment care community was, somehow, prioritized. This Agency of Living Environment has opted for a group communication channel by involving public figures in giving socialization to society. In this case, the public figures and cultural guardians became a government extension and a mouthpiece of the people that had a highly significant role 
in developing mangrove forest ecotourism (Setyowati, 2010).

The success of the tourism destination cannot be relinquished from the government's pivotal role as a provider of tourism infrastructure (Ridlwan et al., 2017). The government created the groups/communities which were facilitated with some aids like nursery fees, polybags, and farming equipment. Besides, the Agency of Living Environment of Bengkalis Regency invoked each chief of the village to supervise the program to be well-implemented. Concerning communication affairs, the government involved various elements like the Agency of Marine and Fisheries, the chief of villages, and the public figures. Unfortunately, this coordination did not involve wider stakeholders. Indeed, the development of this ecotourism did not involve the Agency of Government Tourism, whereas integrated tourism communication marketing needed a coordinated and integrated approach between interpersonal communication and other communication channels (Karta \& Suarthana, 2014).

The environmental communication practiced by Kempas could be deemed successful in motivated successful in motivating, inspiring, and enhancing people's environmental awareness on mangrove forests. The chosen communication channel bolstered this success in combination with word of mouth (Gethok Tular). The meaning of Gethok Tular is a communication from one person to another, which is exceptionally effective in delivering information to communities about environmental sustainability (Darmastuti, Bajari, Martodirdjo, \& Maryani, 2017). This communication success is proven by the plantation of a new mangrove forest located in Pangkala Batang Village, a village that is located side by side with Sebauk Village. Besides, there was a demand escalation of mangrove seeds from other groups, which would be planted in their territories as an attempt to avoid their territories from abrasion and to imitate other groups in developing mangrove ecotourism area.

The interpersonal communication through intensive coaching practiced by the officials made environmental communication productive. Interpersonal communication had a role as a connector among individuals or groups. The selection of the group communication channel is powerfully effective in empowering the society, moreover, if it is strengthened by a participative communication approach (Amanah, 2010; Yasir, Nurjanah, \& Yesicha, 2017). The government's policy and support through proper and sustainable communication are exceptionally significant in succeeding in this mangrove ecotourism program.

\section{Message Development and Media Production}

This phase consists of the steps to develop messages and produce media. The combination of message and media is taken into consideration based on the audiences (Jurin et al., 2010). Media is much essential to result in, produce, and distribute the messages, both done by the government or society (Yasir et al., 2017). The environmental communication message is directed to change the public's habit that does not care for the environmental issue. The branding of an environmental communication message was practiced by the Agency of Living Environment and a community like Kempas. The messages delivered by the government were still formalistic, instruction in the form of socialization like conducting coaching and training toward several communities. The socialization and establishment of those environmental management groups were motivated by the issue of environmental damage. Besides, the government preserved and maintained ecosystem equilibrium to sustain the coastal environment by replanting the mangrove forest. 
Environmental communication runs effectively if the messages are transformed into a designed campaign (Jurin et al., 2010). The government used messages to appeal and persuade society in order to preserve and conserve the ecosystem through the billboard platforms in several coasts. This message adapted to the coastal condition of the Bengkalis Regency that is damaged due to abrasion. The environmental communication message was presented in a documentation video about the process of Kempas' program management. For example, it was presented in a stand of the Office of Living Environment at the MTQ event in Selatbaru. That video was a kind of environmental promotion and campaign. Furthermore, that stand also showed a physical sketch of mangrove ecotourism master plan.

At that event, the government of the Bengkalis Regency through the Agency of Living Environment provided an appeal and gave an example to the society or event visitors to always care about the mangrove forest. Besides, the other media were used, such as warning boards, banners, or billboard media. That message was produced with the hope that society and visitors in the ecotourism location have a responsibility for preserving the environment.

\section{Program Implementation and Communication Evaluation}

This phase consists of management steps to implement message distribution through media, real action, monitoring, and evaluation. The plan of environmental communication must always enclose a description of how the project will be evaluated (Jurin et al., 2010). The communication evaluation in an attempt to encourage society toward the environment of mangrove forests in Bengkalis has not, indeed, operated because its evaluation was not maximally executed. Moreover, rehabilitating and conserving mangroves require sustainable supervision and maintenance (Rusdianti \& Sunito, 2012). The key to environmental communication is the priority and commitment of the implementation of the government's policies. The implementation of the distribution policy of environmental communication messages must be orderly coordinated among institutions and well-integrated between various kinds of media and communication channels. Hence, the process of monitoring and evaluation of environmental communication programs in developing ecotourism cannot be instantly practiced. It must be exercised regularly and continually by upholding deliberation and cooperation principles.

Environmental communication, by deliberation, is a unique social culture. The members of society consistently conducted deliberation and cooperation in solving the problem and managing the mangrove area. Whatever the problems were, the result always was decided through deliberation among group members, exactly in evaluating each implemented program. In order to evaluate the development of the program and archive every implemented activity, the documentation was always executed. This documentation was then utilized as a media of campaign in educating and empowering society and other groups that are interested in following the program.

The implementation of tourism development can enhance people's awareness and participation in conservation activities as long as it is beneficial for them ((Haris, Soekmadi, \& Susilo Arifin, 2017). Therefore, the environmental communication program through group empowerment like Kempas could be more effective because it can be an example for society and other groups. This group (Kempas) contributed to the development and enhancement of mangrove replanting movement. Cooperation between Kempas and Indonesian Generation of Enchantment (Genpi) Branch Bengkalis 
by conducting a festival of eating Durian in a mangrove forest area could promote the Sebauk mangrove ecotourism. Besides, this festival enabled us to increase people's awareness and concern in preserving the environment.

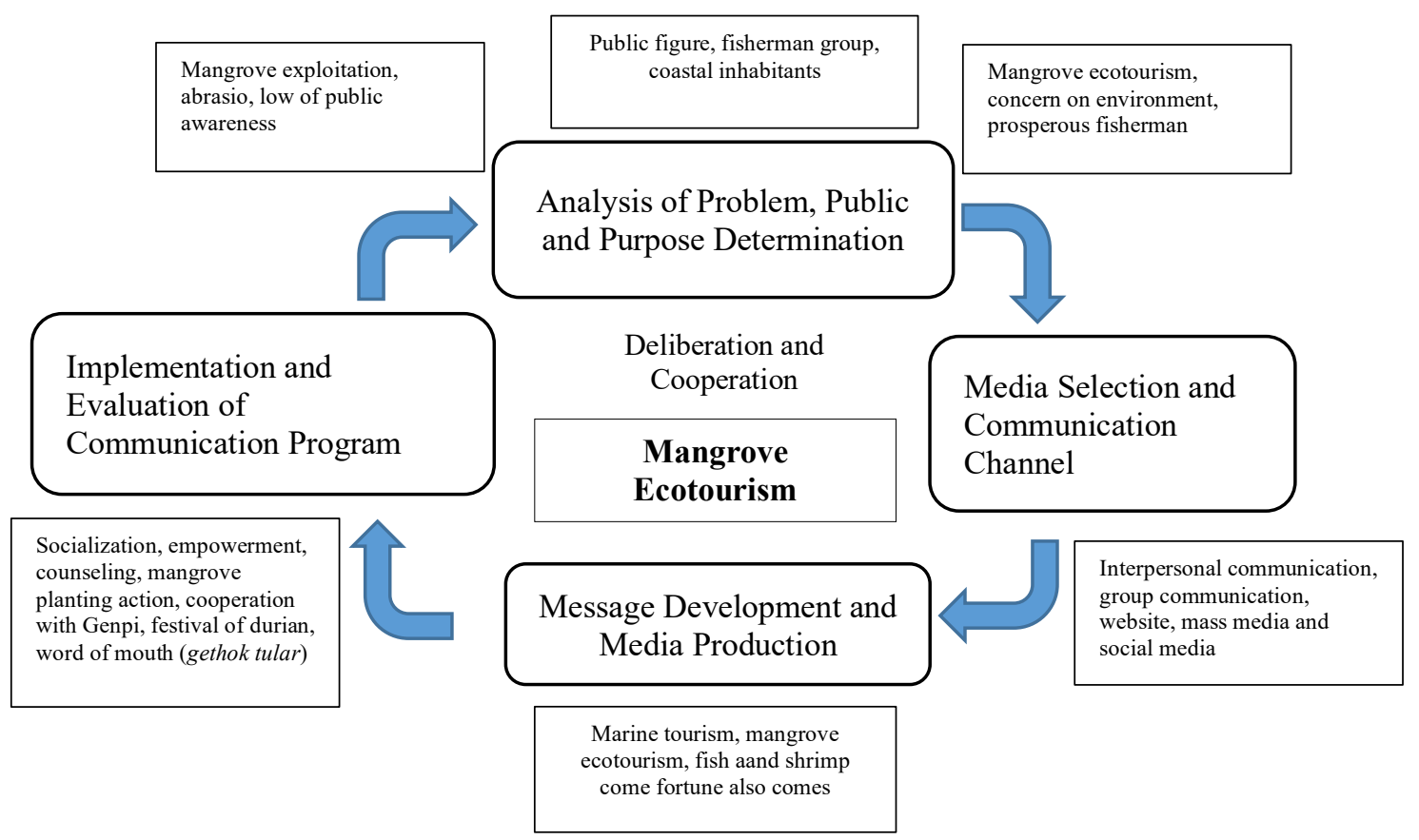

Figure 1. A Model of Environmental Communication Plan in Developing Ecotourism in Bengkalis Regency

Environmental communication played a significant role in enhancing society's skill to respond appropriately to the signal of the environment that is relevant to the prosperity of human civilization and biological systems (Cox, 2010). In this context, the Agency of Living Environment of Bengkalis Regency owns a vital role in making policy and a communication plan to solve the environmental problems in Bengkalis Regency. According to the Regulation of Ministry of Home Affairs, Number 33 of 2009, Article 1 Section 6, "the subjects of ecotourism are government, regional government, business unit, and society that focuses on the tourism sector." (Pemerintah, 2009).

Environmental communication in developing mangrove ecotourism should use communication management by applying various methods and communication channels that are more creative. The communication that was implemented, indeed, should be dialogic or interactive by using a deliberation and cooperation model. The communication of government had not strengthened the messages of mangrove deforestation, abrasion, and the importance of preserving mangrove forests as ecotourism, particularly messages pointed for the public. Environmental communication must be continually evaluated to develop sustainable mangrove ecotourism that is striving for perfection, namely the preservation of mangrove and the prosperity of society.

\section{Environmental Communication Model Based on Deliberation and Cooperation}

Environmental communication is highly significant in increasing people's and governments' awareness, motivation, and concern in preserving and utilizing mangrove 
responsibly. The model of mangrove forest management has been regulated in the Regulation of President of Indonesia Republic Number 73 of 2012 concerning National Strategy on Mangrove Ecosystem Management (SNPEM). This regulation regulates policies and programs to manifest sustainable mangrove ecosystem management and sustainably prosperous society based on the available resources as an integral part of the national development planning system (Pemerintah, 2012). This regulation also regulates mangrove forest management, which must create a coordination team both at the national level, province level, and regional level.

The communication program of mangrove forest conservation becomes a significant element to be prioritized. Based on that Presidential Regulation, the problem of abrasion and mangrove forest damage in the Bengkalis Regency are quite worrying, which are not only the concern of government but also the concern of society. So, it is necessary to conduct sustainable communication to find a solution. The anxiety of mangrove deforestation and abrasion that can sink the land or people's villages can be a primary agent of change in society (Darmastuti et al., 2017). Hence, the Agency of Living Environment and the Office of Fisheries and Maritime of Bengkalis Regency coordinated by involving some relevant institutions and society to solve the problems with deliberation. The government, through the Agency of Living Environment, conducted socialization by creating and empowering communities to preserve the mangrove forest. As a result, it can be managed as mangrove ecotourism.

The basic concept of mangrove ecotourism involves three main aspects; those are the economy, social, and environment. If those aspects can be well integrated, sustainable tourism will be self-established (Karta \& Suarthana, 2014). The activity conducted by the Agency of Living Environment of Bengkalis Regency in Sebauk Village was integrated program coordination among relevant institutions of the Regional Government of Bengkalis Regency, particularly with the Agency of Fisheries and Maritime. This activity is an effort to enhance social participation on the environmental issue, which then can increase people's income through forest conservation and mangrove ecosystem program.

The empowerment of mangrove care groups has been implemented by the Agency of Fisheries and Maritime and the Agency of Living Environment by giving socialization, coaching, training, facilitation, and monitoring. The communication channels that were used for empowerment were interpersonal communication, mass communication (mainly through social media), and competition among groups. Through the implementation of empowerment, the communication used is mostly via interpersonal communication and group communication. Those two communication channels aim to implement a collaborative approach (silaturrahim). In other words, the communication used prioritizes deliberation and cooperation principles. As a result, the collaborative approach tried to involve the communities directly, exactly residents and government officers.

Interpersonal and group communication are based on the dialogical or interactive pole. Therefore, the government and communities can understand and influence one another. These forms of communication of friendship (silaturrahmi), deliberation, and cooperation with a kinship approach were the social process and local wisdom of the residents, which inherited hereditarily. It was not strange if environmental communication to develop mangrove ecotourism programs can be conducted by sharing their respective roles and responsibilities. The communication which still prioritizes the local cultural values becomes value-added for the advantage of 
this environmental communication model. This is strengthened by a study conducted by Bakti et al., which explained that local wisdom-based communication through the interpersonal friendship (silaturrahmi) forum of traditional elders and discussion groups of cultural and tourism activists could establish understanding, agreement, cooperation, and collaboration. The communication group channels also possessed high conformity and cohesiveness that can develop geo park tourism destination based on local culture and local wisdom. Moreover, social media was utilized to send and receive information, which then strengthens the social relations among them that can also develop a tourism destination (Bakti et al., 2018).

A deliberation-based environmental communication model was conducted by each member of the groups regularly according to the group agreement. Each deliberation activity involved not only the members of the groups but also representatives from the village and regency government. The deliberation delivered, evaluated, and interpreted environmental problems collectively. Mainly, the point of the deliberation was pressure towards the government to supervise, coach, educate, and fund the group to solve the problems in the village they lived in. Regarding this, ethnoecology communication showed that there are several groups of interpretation in society toward their surrounding environment, such as river, beach, or forest. The meaning emerges from a continuous process of two primary factors, namely yearly personal experiences, stories, and parents' education, and collective or peer experiences (Yenrizal, 2016).

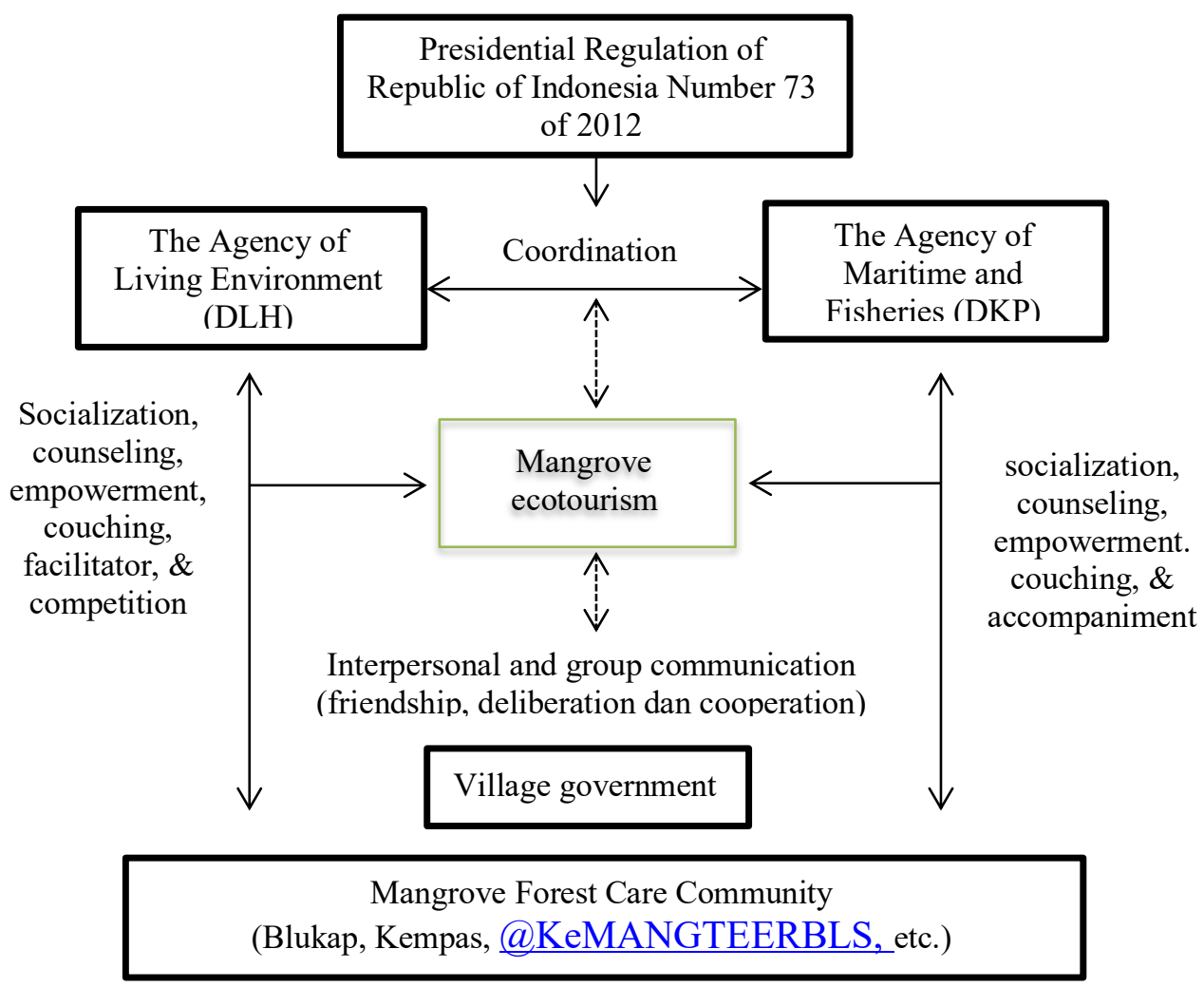

Figure 2: Deliberation-based Environmental Communication

In managing the environment and interpret mangrove forests, the Agency of Living Environment of Bengkalis regency socialized, coached, and facilitated community that cares about mangrove forests, such as Blukap, Kempas, and Kelompok 
Jaya. The Agency of Marine and Fisheries, on the other hand, figure in directing the coastal land management to be mangrove ecotourism program. The Agency of Tourism, however, had not involved itself in coaching the groups that developed the mangrove ecotourism, even though the Agency of Tourism had a program to coach tourismconscious groups (POKDARWIS) for each tourism destination. Therefore, the development of mangrove ecotourism would be more successful if the Agency of Tourism contributed directly to coaching and empowerment. This because empowerment means accelerating sources, opportunity, knowledge, and skills to expand the capacity in determining the future of communities (Subekti, Setianti, \& Hafiar, 2018; Yasir et al., 2017).

Participatory Rural Appraisal (PRA) is a model in which "outsiders" put himself in the middle of a community to help. The "outsider" can be government officials, members of the non-government organization, or academician, which is expected to encourage the people to improve their knowledge and analyze their condition (Setyowati, 2010). In this context, the government of Bengkalis had tried to empower, coach, and accompanied the people by assisting in searching for companies that want to develop the mangrove forest and become their Corporate Social Responsibility (CSR). Lately, the Blukap group in Teluk Pambang Village was approved to be a coached and partnered group of CSR Chevron Pacific Indonesia (CPI) and Yayasan Konservasi Nusantara through Mangrove Ecosystem Restoration Alliance (MERA). Presidential Regulation of the Republic of Indonesia, Number 73 of 2012, motivated the regional government of Riau to ask companies to assist in developing mangrove governance in Riau (Turnip, 2019).

Furthermore, the environmental campaign towards mangrove preservation in Bengkalis Regency was also conducted in the virtual community on social media. Therefore, in addition to coaching the groups that care about mangrove, the government also coached virtual communities such as KeMANGTEER (Kelompok Mangrove Masketeer) of Bengkalis. On October 20, 2016, the KeMANGTEER of Bengkalis was established in Kelapapati Village. It was established and active in the virtual world, specifically on Twitter, at @KeMENGTEERBLS, as opposed to other social media platforms. KeMANGKETEER Bengkalis is a part of the other 12 active KeMANGKETEER in Indonesia. This community was also coached by the Agency of Living Environment, whether in terms of training or socialization.

Different groups caring about the preservation of mangrove were coached in many ways by the government. The activity was related to mangrove preservation, such as mangrove seeds planting, beach clean-up, and mangrove processing training. In this context, communication, whether between the government, groups, and society, became an essential process to realize a society that is aware and conscious of the mangrove environment. That is, the government does not monopolize communication. By contrast, influence can come from community involvement and affect government policy.

Many experts have developed communication models in different contexts, but in the context of environmental communication, Lawrence Kincaid and Everett M. Rogers have developed a communication model based on the principle of concentration. It was developed from information theory and cybernetic (Cangara, 2013; Flor \& Cangara, 2018). This model develops a communication process that happens with a dialog. A dialog or deliberation is perceived as a useful communication model because, in a dialog, the communication process is two-ways. Deliberation and cooperation, as run by the government of the Bengkalis Regency, was a communication that involves the 
people actively. Indeed, people have the same right to voice, enabling agreement and problem solving to be more productive.

Communication model groups like Blukap and Kempas, as the group that managed the mangrove ecotourism, dominantly conducted deliberation and cooperation among members. They developed a communication model through deliberation to solve environmental problems that available in their community, especially abrasion and mangrove deforestation. Environmental issues that they communicated were motivated by a reality that their villages had been crushed by abrasion; fish, shrimp, and other ocean resources had begun challenging to find; and the saltwater had infiltrated the land. The fishermen and people who lived near the beach interpreted the natural message as a reprimand of God due to negligence in preserving nature. This is why the groups that were active in preserving and sustaining the mangrove were formed out of a shared mission to recover the damaged nature. In addition, improving the welfare of the members is also the primary aim.

Integrated marketing communication calls for a coordinated approach between interpersonal communication with other communication channels (Karta \& Suarthana, 2014). Integrated communication activities did not frequently execute by the officials of the Bangkalis Regency. However, as a group that was relied on by the government, Kempas, in its attempt to develop mangrove ecotourism, used interpersonal communication channels, especially between public figures in the village, and between related officials. The interpersonal communication of Kempas discusses the program they planned to execute. Each member of the group interpreted interpersonal communication as a friendship event.

Apart from interpersonal communication, the group communication channel cannot be neglected in environmental communication in the development of ecotourism. Group communication aimed to discuss programs in developing the mangrove ecotourism. Indeed, this group communication alleviated the members of the group in solving the problems and making a decision. Furthermore, it accelerated the implementation of the activity, especially in work divisions and cooperating. In addition, group communication was also done to keep and enhance solidarity among members.

Besides interpersonal and group communication, the members of Kempas also conducted public communication on many occasions, especially in the village government activity. This activity aimed to be closer to the broader society as an attempt to ease Kempas in the socializing program they have. Not only that, the governments even campaigned about the environment to the broader society by exemplifying Kempas as a group that succeeds in managing mangrove ecotourism. Communication of this model socialized not only the government program of Bengkalis Regency in protecting and preserving mangrove forests but also group coaching. The government communicated or campaigned environmental issues, mangrove deforestation, and abrasion to limited groups of people. It had not strengthened by social media movement as a communication trend in the digital era and the most popular media used by society. At least, there would be integration and mixed communication channels in campaigning the preservation of mangrove forests, especially in realizing mangrove ecotourism first-class in Bengkalis regency. 


\section{Conclusion}

Environmental communication planning in the development of mangrove ecotourism in the Bengkalis Regency has not figured as a significant component and even not integrated and coordinated holistically with other institutions. Environmental communication cannot be abandoned because it functions as a supporter of policymakers, community participation, and implementation of environmental awareness. Environmental communication in the development of the Bengkalis Regency has at least followed the communication planning process with several stages. Firstly, situation analysis and identification of social, economic, and environmental problems related to the assessment of the developmental program of mangrove as ecotourism. This stage also analyzed the actors or audiences who were involved in determining the objective of communication, namely, giving understanding, awareness, and sensitivity towards mangrove forests. Secondly, media selection and communication channel that cover the development of communication strategy and approach in motivating and mobilizing community. Thirdly, the message development and media production that attempt that messages should be packaged well and accurate. Fourthly, the implementation of the program and evaluation of communication, which involves the implementation stage, also called for a well and sustainable arrangement. The fourth stage also included management in monitoring, documentation, and evaluation of environmental communication activities in mangrove ecotourism development.

The model of environmental communication to develop mangrove environmental ecosystem in Bengkalis regency used social empowerment principles that were based on deliberation and partnership by the society mentioned. Environmental communication became the aspect that is essential in developing mangrove ecotourism, and it should be implemented integrative. Planning and implementation of environmental communication should be creative and coordinated among elements of society, primarily the Agency of Environment and Agency of Tourism. The researchers recommend that further development establishes an environmental communication model that is based on culture and local wisdom with an ethnographical communication approach towards another local community.

\section{References}

Amanah, S. (2010). Peran Komunikasi Pembangunan dalam Pemberdayaan Masyarakat Pesisir. Jurnal Komunikasi Pembangunan, 8(1), 1-19.

Astuti, D., \& Widodo, T. (2018). Identifikasi Potensi Serta Minat Konsumen akan Ekowisata Mangrove di Pulau Bengkalis. Jurnal Inovasi Dan Bisnis, 6, 135-141.

Bakti, I., Sumartias, S., Damayanti, T., \& Nugraha, A. R. (2018). Pengembangan Model Komunikasi Pariwisata Berbasis Kearifan Lokal di Kawasan Geopark $\begin{array}{llll}\text { Pangandaran. Jurnal Kajian } & \text { Komunikasi, }\end{array}$ https://doi.org/10.24198/jkk.v6i2.18459

Cangara, H. (2013). Perencanaan dan Strategi Komunikasi. Jakarta: Rajawali Press.

Cox, R. (2010). Environmental Communication and the Public Sphare. California: Sage Publication.

Darmastuti, R., Bajari, A., Martodirdjo, H. S., \& Maryani, E. (2017). Gethok Tular, Pola Komunikasi Gerakan Sosial Berbasis Kearifan Lokal Masyarakat Samin di Sukolilo. Jurnal ASPIKOM, 3(1), 104. https://doi.org/10.24329/aspikom.v3i1.103

Flor, A. G., \& Cangara, H. (2018). Komunikasi lingkungan: Penanganan Kasus-kasus 
Lingkungan Melalui Strategi Komunikasi (Pertama). Jakarta: Prenadamedia Group.

Haris, M., Soekmadi, R., \& Susilo Arifin, H. (2017). Potensi Daya Tarik Ekowisata Suaka Margasatwa Bukit Batu Kabupaten Bengkalis Provinsi Riau. Jurnal Penelitian Sosial Dan Ekonomi Kehutanan, 14(1), 39-56. https://doi.org/10.20886/jpsek.2017.14.1.39-56

Jurin, R. R., Roush, D., \& Danter, K. J. (2010). Environmental Communication. Second Edition. In Environmental Communication. Second Edition. https://doi.org/10.1007/978-90-481-3987-3

Karta, N. L. P. agustini, \& Suarthana, I. K. P. (2014). Strategi Komunikasi Pemasaran Ekowisata pada Destinasi Wisata Dolphin Hunting Lovina. Jurnal Manajemen Strategi Bisnis Dan Kewirausahaan, 8(1), 45-51. Retrieved from https://ojs.unud.ac.id/index.php/jmbk/article/view/8076

Lestari, P., Paripurno, E. T., Kusumayudha, S. B., \& Ramadhaniyanto, B. (2016). Komunikasi Lingkungan untuk Mitigasi Erupsi Gunung Sinabung. Jurmal ASPIKOM, 3(1), 56-64.

Littlejohn, S., \& Foss, K. A. (2016). "Encyclopedia of Communication Theory”. Sage Publication. Terjemahan Tri Wibowo BS. Ensiklopedia Teori Komunikasi. Jakarta: Kencana.

Miswadi, Firdaus, R., \& Jhonnerie, R. (2017). Pemanfaatan Kayu Mangrove oleh Masyarakat Suku Asli Sungai Liong Pulau Bengkalis. Dinamika Maritim, 6(1), 35-39. Retrieved from http://ojs.umrah.ac.id/index.php/dinamikamaritim

Moleong, L. J. (2010). Metode Penelitian Kulaitatif. Bandung: Remaja Rosdakarya.

Pemerintah Indonesia. (2012). Praturan Presiden Republik Indonesia Nomor 73 Tahun 2012 Tentang Strategi Nasional Pengelolaan Ekosistem Mangrove. Jakarta: Presiden Republik Indonesia.

Pemerintah, P. (2009). Peraturan Menteri Dalam Negeri Nomor 33 Tahun 2009 Tentang Pedoman Pengembangan Ekowisata Di Daerah. Jakarta: Menteri Dalam Negeri.

Putra, A. C., Anggoro, S., \& Kismartini. (2015). Strategi Pengembangan Ekowisata Melalui Kajian Ekosistem Mangrove di Pulau Pramuka, Kepulauan Seribu. Jurnal Saintek Perikanan, 10(2), 91-97. https://doi.org/10.3141/2279-14

Ridlwan, M. A., Muchsin, S., \& Hayat, H. (2017). Model Pengembangan Ekowisata dalam Upaya Pemberdayaan Masyarakat Lokal. Politik Indonesia: Indonesian Political Science Review, 2(2), 141. https://doi.org/10.15294/jpi.v2i2.9933

Rusdianti, K., \& Sunito, S. (2012). Konversi Lahan Hutan Mangrove Serta Upaya Penduduk Lokal Dalam Merehabilitasi Ekosistem Mangrove. Sodality: Jurnal Sosiologi Pedesaan, 6(1). https://doi.org/10.22500/sodality.v6i1.5815

Setyowati, R. M. (2010). Strategi Komunikasi Yang Mendukung Perkembangan Parwisata Berbasis Ekonomi Kerayaktan. The Messenger, 2(2), 11-15.

Subekti, P., Setianti, Y., \& Hafiar, H. (2018). Pemberdayaan Masyarakat Berbasis Lingkungan Hidup Di Desa Margalaksana Kabupaten Bandung Barat. Jurnal Kawistara, 8(2), 148. https://doi.org/10.22146/kawistara.30379

Susanto, I. (2019). Restorasi Mangrove untuk Tangani Abrasi Riau. Retrieved from Kompas website: https://bebas.kompas.id/baca/utama/2019/07/26/restorasimangrove-untuk-tangani-abrasi-riau/

Turnip, W. M. (2019, September 5). Chevron Bersama MERA, Kembangkan Tata Kelola Mangrove di Provinsi Riau. Retrieved from 
https://www.goriau.com/berita/baca/chevron-bersama-mera-kembangkan-tatakelola-mangrove-di-provinsi-riau.html

Yasir, Y., Nurjanah, N., \& Yesicha, C. (2017). A Model of Communication to Empower Fisherman Community in Bengkalis Regency. MIMBAR, Jurnal Sosial Dan Pembangunan, 33(2), 226. https://doi.org/10.29313/mimbar.v33i2.2135

Yenrizal. (2016). Sungai Dalam Pemaknaan Masyarakat Pedesaan Studi Etnoekologi Komunikasi Pada Masyarakat Desa Karang Anyar, Banyuasin, Sumatera Selatan. Nizham: Jurnal Studi Keislaman, 4(2), 121-130.

Yenrizal, Bajari, A., Rahmat, A., \& Iskandar, J. (2015). The meaning and value attachment to natural symbols by farmers in a rural setting: An ethno-ecology communication study of rural farmers in Swarna Dwipe village of Muara Enim regency in South Sumatera. International Journal of Applied Engineering Research, 10(16), 37630-37636. 